Volume 1, Number 1, 2015

\title{
Investigation of Mill Balls Metal Deterioration in Mills KBM 370/850 (Sh-50A) when Fuel not Envisaged in the Mill Design is Used at Thermal Power Plants
}

\author{
Stepan Mysak ${ }^{*}$, Taras Voronchak \\ Lviv Polytechnic National University, Ustyyanovych Str., 5, Lviv, 79013, Ukraine.
}

Received: March 30, 2015. Revised: June 02, 2015. Accepted: July 20, 2015.

(C) 2015 The Authors. Published by Lviv Polytechnic National University.

\begin{abstract}
Method for determining mill balls metal deterioration rate in a ball mill KBM 370/850 (Sh-50A) of dust-system of coal-dust boilers TPP-210A and TPP-312 300MW of thermal power plants is described in the paper. The research is aimed at the development of the determination method of the mill balls deterioration rate in a ball mill, which would allow predicting the regulated refill of the ball mill by the mill balls. The research tasks were to analyze existing literature, to develop the calculation method of the mill balls deterioration rate in the mill, to carry out analytic calculations and obtain analytic relationships of mill balls deterioration rate, and based on this to develop generalized regularities for any dust-systems of thermal power plants. The rank of coal being grinded in the mill, the mill operation mode, design features of dust-system and boiler etc. influence the mill balls deterioration rate.
\end{abstract}

Keywords: ball mill; mill balls; ball load; fuel not envisaged in mill design.

\section{Introduction}

Under present-day conditions of ball mills (BM) operation, the operation modes do not correspond to those calculated in design and do not meet the operational requirements of thermal power plants dust-systems, when grinding the fuels not envisaged in the mill design [1]. In this case the fuel grinding occurs with considerable deviations in BM and dust-system operation.

Continuous BM service without regulated periodical refill of the ball load contributes to intense mill balls deterioration $[2,3,5,8]$. To predict the balls deterioration until the minimum permissible ball load, specific investigations, as well as development of the analytic method of the mill balls deterioration rate calculation are required.

\section{Aim and tasks of the research}

The research is aimed at the development of the calculation method of the mill balls deterioration rate in BM, which would allow predicting the regulated refill of the BM by the mill balls.

The following tasks have been set for this aim

- to analyze existing literature for summarizing materials concerning the research aim.

- to develop the calculation method of the mill balls deterioration rate in BM.

- to carry out analytic calculations and obtain analytic relationships of mill balls deterioration rate for different coal ranks to obtain generalized regularities.

\section{Brief technical characteristics of ball mills}

Ball mill KBM 370/850 (Sh-50A) is designed for grinding the coal of different ranks for further feeding of resulting coal dust into the boiler furnace. The mill barrel of internal diameter $D_{b}=3700 \mathrm{~mm}$ and length $L_{b}=8500 \mathrm{~mm}$ revolves on its own axis with frequency $n_{b}=17.6 \mathrm{rpm}$, that is the main feature of KBM mill.

\footnotetext{
*Corresponding author. Email address: s.mysak@yandex.ru
} 
Number of mills is chosen depending on design parameters of dust-systems, boilers, auxiliary equipment, as well as fuel rank $[3,4]$.

Three individual dust-systems are chosen for boiler TPP-210A of $300 \mathrm{MW}$ power-generating unit. The dustsystem is designed for grinding in BM the ASH rank coal with following characteristics: $Q_{l}^{o}=24.3 \mathrm{MJ} / \mathrm{kg}$, $A^{o}=19 \%, W^{\circ}=7.5 \%, V^{c}=3.5 \%$ and $K=0.95$.

The coal dust with grinding fineness $R_{90}=7 \%$ and humidity $W^{\circ}=0.5 \div 1.0 \%$ should be fed into the furnace. Nominal output of BM: $B=50 \mathrm{t} / \mathrm{h}$.

Boiler TPP-312 of 300 MW power-generating unit has two individual dust-systems with BM. The dust-system is designed for grinding the GHSSH rank coal of Donetsk coalfield with following characteristics: $Q_{l}^{o}=20.9 \mathrm{MJ} / \mathrm{kg}$, $A^{o}=22.3 \%, W^{o}=11 \%, V^{c}=40 \%$ and $K=1.1$.

Calculated characteristics of the coal dust fed into the boiler furnace are as follows: grinding fineness $R_{90}=25 \%$, humidity $W^{\circ}=3.0 \%$. Design nominal dust output of BM $B=76 \mathrm{t} / \mathrm{h}$.

Taking into account the operation and design features of dust-systems with BM being used with different boilers and for different fuel ranks, it can be concluded that estimation of mill balls deterioration and time of regulated refill ensuring BM operation efficiency is still very important.

\section{Method for determining mill balls metal deterioration rate}

Mill balls deterioration rate in BM characterizes the metal loss of the balls, and, consequently, decrease of the ball load in BM, per time unit.

The rank of coal being grinded in BM, the BM operation mode, design features of dust-system and boiler etc. influence the mill balls deterioration rate $[3,5]$. Block-diagram of different factors effect on the mill balls metal deterioration rate in $\mathrm{BM}$ is given in fig. 1.

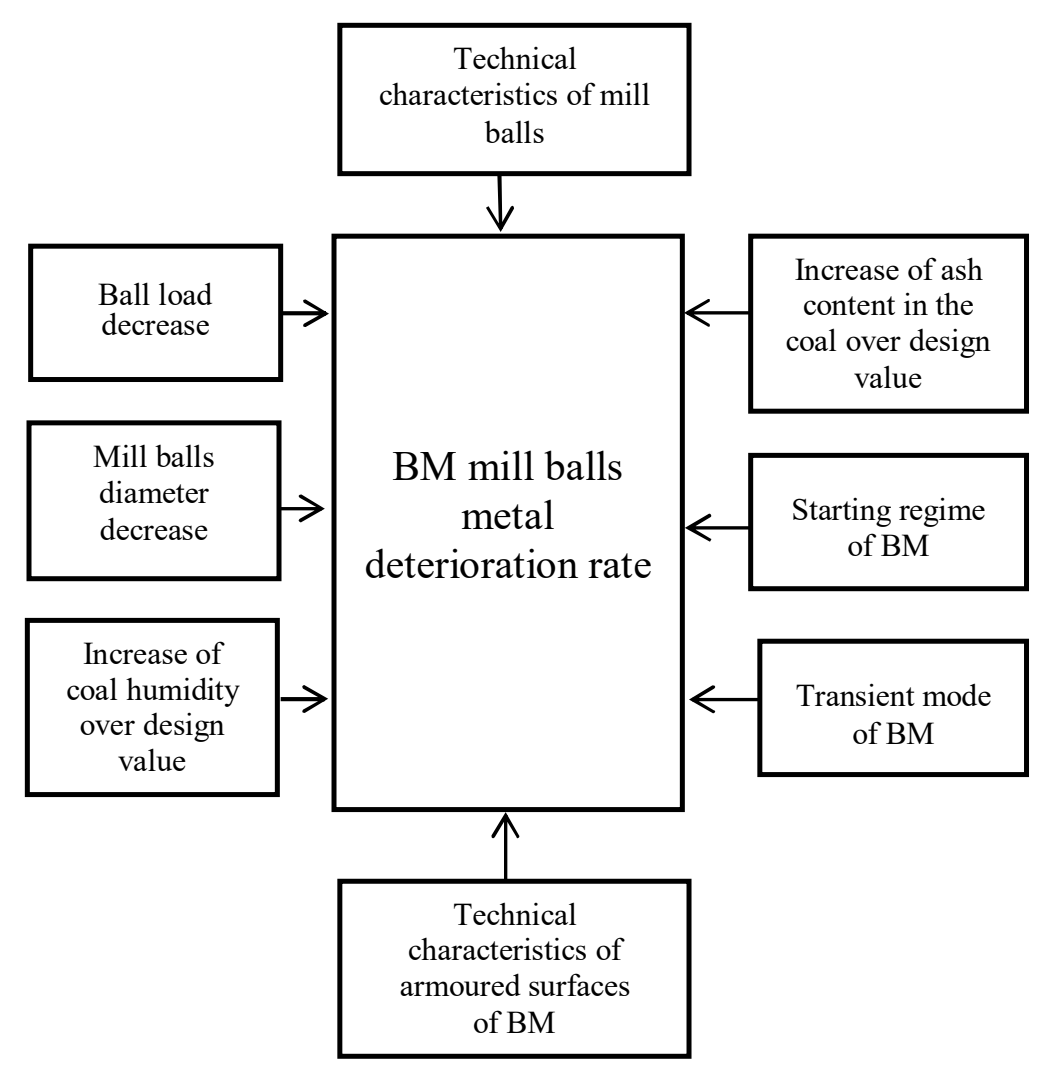

Fig. 1. Block-diagram of different factors effect on mill balls metal deterioration rate in BM using dust-systems of power-generating units of coal-dust thermal power plants 
In practice of BM operating, average value of mill balls deterioration rate for some period is used. However, the factors influencing the mill balls deterioration rate are not taken into account. That is why experimental determination of the average value of the mill balls deterioration rate gives only approximate estimate of actual rate of the mill balls deterioration, and, consequently, the value of ball load decrease. The mill balls metal deterioration after the BM operation period $\tau$ can be determined by the experimental method as follows:

$$
\Delta G_{b}=\int_{0}^{\tau} q_{b i} d \tau
$$

where $q_{b i}-$ mill balls deterioration during the period $\tau$.

Total decrease of mill balls metal mass after $n$ periods of BM operation:

$$
\Delta G_{b}^{t o t}=\sum_{i=1}^{i=n} \int_{0}^{\tau} q_{b i} d \tau
$$

The average value of mill balls metal deterioration rate after $\mathrm{n}$ operation periods:

$$
\Delta q_{b a}^{e x}=\frac{\sum_{i=1}^{i=n} \int_{0}^{\tau} \Delta G_{i}}{\tau_{i}},
$$

where $\Delta G_{i}-$ mill balls metal deterioration in $i^{\text {th }}$ period; $\tau_{i}-$ the $i^{\text {th }}$ period duration.

As was mentioned above, the average value of mill balls metal deterioration rate $q_{b a}^{e x}$ is determined experimentally for certain period $\tau$ of BM operation in stable mode.

The balls deterioration rate changes with the change in the BM operation mode.

New value of mill balls deterioration rate is appropriate to be determined not experimentally but using a method considering the known value of mill balls deterioration rate and corresponding correction factors, namely:

$$
q_{b}^{c}=\frac{\sum_{i=1}^{i=n} \int_{0}^{\tau} \Delta G_{i}}{\tau_{i}} k_{\text {load }} k_{d} k_{\text {hum }} k_{\text {ash }} k_{n} .
$$

Herein $k_{\text {load }}$ - correction factor considering decrease in ball load of the mill barrel. $k_{\text {load }}$ is calculated by the following formula:

$$
k_{\text {load }}=\left(\frac{G_{b}^{d}}{G_{b}^{a}}\right) 0.6
$$

where $G_{b}^{d}$ and $G_{b}^{a}$ - design and actual ball load of BM barrel, respectively.

Correction factor $k_{d}$ considers mill balls diameter decrease after continuous operation of BM. $k_{d}$ is calculated by the formula:

$$
k_{d}=\frac{1}{\sqrt{0.9832}(i+1) i}
$$

where $i$ - number of periods corresponding to $5 \%$ value of ball load of BM barrel compared to previous period:

$$
i=\frac{\lg \frac{G_{b}}{G_{b}^{\max }}}{\lg a},
$$

where $a$ - ball load fraction of the initial ball load of the mill in one certain period which is constant for each period compared to previous one and is equal $a=0.95$. 
Correction factor $k_{\text {hum }}$ characterizes coal humidity increase over the value envisaged in mill design. $k_{\text {hum }}$ is determined by:

$$
k_{\text {hum }}=\left(\frac{W_{d}^{o}}{W_{a}^{o}}\right)^{m}
$$

where $W_{d}^{o}$ and $W_{a}^{o}$ - design and actual coal humidity, respectively, \%; $m$ - exponent characterizing the coal rank. Thus, when grinding the coal of ASH rank, $m=1$, and in case of the coal of GHSSH rank $m=0.65$.

Correction factor $k_{a s h}$ characterizes increase of ash content in the coal over the value envisaged in mill design. $k_{a s h}$ is calculated by:

$$
k_{a s h}=\left(\frac{A_{d}^{o}}{A_{a}^{o}}\right)^{n},
$$

where $A_{d}^{o}$ and $A_{a}^{o}$ - design and actual ash content in the coal, respectively, $\% ; n$ - exponent characterizing the ash content deviation from the value envisaged in mill design.

Correction coefficient $k_{n}$ considering varying operation modes (transient and starting) i.e. non-stable or nonstationary characterizes mill balls metal deterioration due to these modes.

It has been determined based on the operational data that starting mode duration is $0<\tau_{\text {start }}<0.25$ hours and transient mode duration is $0<\tau_{\text {start }}<0.6$ hours.

Total duration of non-stationary modes $\tau_{t o t}$ is equal:

$$
\tau_{\text {tot }}=\tau_{\text {start }}+\tau_{\text {trans }}
$$

and factor $k_{n}$ is calculated by the formula:

$$
k_{n}=k_{\text {start }}+k_{\text {trans }},
$$

where

and

$$
k_{\text {start }}=1+\frac{0.25 n_{\text {start }}}{24-0.25 n_{\text {start }}} \text {, }
$$

$$
k_{\text {trans }}=1+\frac{0.6 n_{\text {trans }}}{24-0.6 n_{\text {trans }}},
$$

where $n_{\text {start }}$ and $n_{\text {trans }}$ - number of starts and transient processes.

New value of mill balls deterioration rate $q_{b}^{c}$ can be calculated by the formula:

$$
q_{b}^{c}=q_{b a}^{e x} k_{\text {load }} k_{d} k_{\text {hum }} k_{\text {ash }} k_{\text {start }} k_{\text {trans }} .
$$

\section{Calculation of the correction factors and mill balls metal deterioration rate in BM}

Calculation of the correction factors and mill balls metal deterioration rate in BM was carried out by the suggested method using experimental research data obtained in boiler TPP-312 of 300 MW power-generating unit $[6,7]$.

The main design objectives assumed in calculations of mill balls deterioration rate in mill KBM 370/850 (SH-50A) were as follows:

maximum ball load of the mill $G_{b}^{d}-87 \mathrm{t}$;

fuel humidity $W^{\circ}=7,5 \%$;

coal dust output $B=50 \mathrm{t} / \mathrm{h}$;

The results of experimental and computational determination of correction factors and mill balls metal deterioration rate in BM of boilers TPP-312 of 300 MW power-generating unit are given in Table 1. 
Table 1. The results of experimental and computational determination of mill balls metal deterioration rate in BM of dust-system of boiler TPP-312

\begin{tabular}{|c|c|c|c|c|}
\hline \multirow{2}{*}{ Name } & \multicolumn{4}{|c|}{ Experiment } \\
\hline & 1 & 2 & 3 & 4 \\
\hline \multicolumn{5}{|l|}{$\begin{array}{l}\text { Experimental determination of balls } \\
\text { deterioration }\end{array}$} \\
\hline Fuel combustion heat $Q_{l}^{o}, \mathrm{MJ} / \mathrm{kg}$ & 21.24 & 22.20 & 21.81 & 21.84 \\
\hline Ash content in fuel $A^{o}, \%$ & 21.3 & 19.8 & 20.40 & 20.35 \\
\hline Ash content in dry fuel $A^{d}, \%$ & 23.6 & 21.7 & 22.4 & 22.4 \\
\hline Fuel humidity $W^{\circ}, \%$ & 8.55 & 8.4 & 8.85 & 9.6 \\
\hline Residue on the sieve $R_{90}, \%$ & 37.6 & 37.8 & 39.0 & 36.7 \\
\hline Operation period $\tau$, hours & 0 & 245.0 & 591.0 & 941.5 \\
\hline Ball load $G_{b}$, tons & 84.0 & 80.5 & 76.0 & 69.5 \\
\hline Mill balls metal deterioration rate $q_{b i}, \mathrm{~kg} / \mathrm{h}$ & - & 14.3 & 13.5 & 15.4 \\
\hline $\begin{array}{l}\text { Average mill balls metal deterioration rate } \\
\qquad q_{b a}^{e x}, \mathrm{~kg} / \mathrm{h} .\end{array}$ & \multicolumn{4}{|c|}{14.4} \\
\hline $\begin{array}{c}\text { Calculation by the method } \\
\text { Correction factors: } \\
k_{\text {load }} \\
k_{d} \\
k_{\text {hum }} \\
k_{\text {ash }} \\
k_{\text {start }} \\
k_{\text {trans }} \\
\end{array}$ & $\begin{array}{l}1.01 \\
1.01 \\
1.00 \\
1.00 \\
1.00 \\
1.00 \\
\end{array}$ & $\begin{array}{l}1.02 \\
1.01 \\
1.03 \\
1.00 \\
1.00 \\
1.01 \\
\end{array}$ & $\begin{array}{c}1.05 \\
1.04 \\
1.065 \\
1.01 \\
1.00 \\
1.01 \\
\end{array}$ & $\begin{array}{l}1.10 \\
1.12 \\
1.10 \\
1.01 \\
1.01 \\
1.00 \\
\end{array}$ \\
\hline Known balls deterioration rate $q_{b}^{o}, \mathrm{~kg} / \mathrm{h}$ & \multicolumn{4}{|c|}{12.75} \\
\hline $\begin{array}{l}\text { Balls deterioration rate in the experiments } \\
q_{b i}, \mathrm{~kg} / \mathrm{h}\end{array}$ & 13.0 & 13.66 & 15.13 & 17.64 \\
\hline Calculated balls deterioration rate $q_{b}^{a}, \mathrm{~kg} / \mathrm{h}$ & \multicolumn{4}{|c|}{14.85} \\
\hline
\end{tabular}

Researches were carried out at different ball load and different caloric value of GHSSH rank fuel of Donetsk coalfield.

Comparative analysis showed that in the investigated ranges of ball load, ash content in the fuel and fuel humidity the difference between the mil balls deterioration rate values obtained by calculations by suggested method and those obtained by the experimental research is insignificant. The mill balls deterioration rate value obtained experimentally is $q_{b}^{e x}=14.4 \mathrm{~kg} / \mathrm{h}$, and the value obtained by suggested method is $q_{b}^{c}=14.85 \mathrm{~kg} / \mathrm{h}$.

\section{Conclusions}

1. Under present-day conditions of operation of coal-dust boilers with BM, the intense deterioration of dustsystem mechanisms, in particular mill balls, occurs when the fuel not envisaged in mill design is used.

2. Developed method of BM mill balls deterioration rate allows detecting the ball load decrease in the mill when fuels not envisaged in the mill design are combusted at thermal power plants. It also allows determining total losses of balls metal during interrepair periods, and time of regulated refill of the balls.

3. Based on the calculations and research results, the correction factors values were found to depend on the actual operation conditions of BM as well on the fuel rank, and considerably increase in case of deviation of BM operation conditions of dust-systems from design values. 
4. The calculations of mill balls deterioration rate in mills KBM 370/850 (SH-50A) when grinding the GHSSH rank coal of Donetsk coalfield for boilers TPP-312 of 300 MW power-generating unit show that the mill balls deterioration rate is $q_{b}^{c}=14.85 \mathrm{~kg} / \mathrm{h}$.

\title{
References
}

[1] Technical maintenance of power plants and electric grids. Regulations. GKD 34.20.507 - 2003. - Kyiv : OEP "GRIFREE" - 2003. - 611 p. (in Ukrainian)

[2] Calculations and design of coal dust preparation systems of boiler plants (regulations). - Lviv : CKTI - VTI, 1971. - 231 p. (in Russian)

[3] Coal dust preparation at thermal power plants / H. T. Levit. - Moscow : Energoatomizdat, 1991. - 275 p. (in Russian)

[4] Heat engineering tests of boiler plants / V. I. Trembovlia. - Moscow : Energoatomizdat, 1991. - 245 p. (in Russian)

[5] Preparation and grinding of fuel at power plants / A. N. Lebedev. - Moscow : Energiya, 1969. - 520 p. (in Russian)

[6] Holyshev L. V. Ball mill output determination when grinding the coal of reduced quality / L. V. Holyshev, J. S. Mysak, T. Yu. Kravets // Energetika i elektificatsyya - 2000. - No. 8. - P. 14-15. (in Ukrainian)

[7] Holyshev L. V. Determination of correction factors for specific loss of mill balls when grinding ASH rank coal / L. V. Holyshev, J. S. Mysak, Yu. M. Mishchenko, T. Yu. Kravets // Energetika i elektificatsyya. - 2005. - No. 10. - P. 6-9. (in Ukrainian)

[8] Holyshev L. V. Definition of indicators of KBM armor wearing when milling ASh grade coal / L. V. Holyshev, J. S. Mysak, P. Yu. Omelyanovskyy ; ed. P. Omelyanovsk and Y. Mysak // Thermal energy - new challenges. - Lviv : NPF "Ukrainian technologies" 2010. - P. 122-128. (in Ukrainian)

\section{Дослідження зношення металу молольних куль млинів типу КБМ 370/850 (Ш-50А) під час використання на ТЕС непроектних видів палив}

\author{
Степан Мисак, Тарас Ворончак \\ Національний університет “Львівська політехніка”, вул. Устияновича, 5, Львів, 79013, Украӥна.
}

\begin{abstract}
Анотація
Описано метод визначення темпу зношення металу молольних куль кульового барабанного млина 370/850 (Ш-50А) пилосистем пиловугільних котлів ТПП-210А та ТПП-312 300 МВт енергоблоків теплових електричних станцій. Метою досліджень $є$ розроблення методу визначення темпу зношення молольних куль для КБМ, який дає змогу вести прогнозування регламентного поповнення барабана млина молольними кулями. Задачею дослідження було провести аналіз існуючих джерел, розробити метод визначення темпу зношення молольних куль для КБМ та провести аналітичний розрахунок та отримати аналітичні залежності темпу зношення металу молольних куль і на основі цього розробити узагальнені залежності для інших пилосистем енергоблоків ТЕС. На темпи зношення малольних куль впливає марка вугілля, що розмелюється в КБМ, режими його роботи, конструктивні особливості пилосисетми котла та інші фактори.
\end{abstract}

Ключові слова: кульовий млин; молольні кулі; кульове завантаження; непроектне паливо. 